\title{
PENGARUH PEMBERIAN EKSTRAK DAUN KELOR (MORINGA OLEIFERA) SEBAGAI UPAYA PREVENTIF KERUSAKAN HISTOPATOLOGI PANKREAS TIKUS PUTIH (RATTUS NORVEGICUS) YANG DIINDUKSI ALOKSAN
}

\author{
Yesi Nurmalasari ${ }^{1}$, Rakhmi Rafie ${ }^{2}$, Devita Febriani Putri ${ }^{3}$, Vivi Diah Permatasari ${ }^{4}$ \\ Medical Nutrition Departement of Medical Faculty Malahayati University ${ }^{1}$ \\ Public Health Departement of Medical Faculty Malahayati University ${ }^{2}$ \\ Parasitology Departement of Medical Faculty Malahayati University ${ }^{3}$ \\ Medical Student of Medical Faculty Malahayati University ${ }^{4}$ \\ yesinurmalasari.dr@gmail.com ${ }^{1}$, vivi.permarasari3009@gmail.com²
}

\begin{abstract}
Many factors can cause damage to pancreatic beta cells, one of which is diabetogenic substances, diabetogenic substances that can be toxic are alloxan compounds. Moringa plants contain antioxidants such as ascorbic acid, flavonoids, phenolics and carotenoids which function as body protectors from damage to cells that can be caused by free radicals. To The purpose of this study was to determine the effect of Moringa oleifera leaf extract as a preventive measure against the histopathological damage to the pancreas of the male white rat (Rattus norvegicus) Wistar strain induced by alloxan. using pure experimental method post test with control group design. The sample used was 30 male rats. The variables studied were the histopathological features of the pancreas. Data analysis used univariate and bivariate analysis which were processed using a computerized system with the Kruskal-Wallis test. The results of the Kruskal-Wallis test study showed a significant difference between the treatment groups on the histopathological damage of the pancreas $(p<0.05)$. There is a significant effect of giving Moringa oleifera leaf extract as a preventive measure against the histopathological damage to the pancreas of white rats (Rattus norvegicus) male Wistar strain induced by alloxan.
\end{abstract}

Keywords : : Moringa Leaves, Histopathology, Pancreas, Alloxan

\begin{abstract}
ABSTRAK
Banyak fakor yang dapat menyebabkan kerusakan sel beta pankreas salah satu nya yaitu zat diabetogenik, zat diabetogenik yang dapat bersifat toksik adalah senyawa aloksan. Tanaman kelor memiliki kandungan antioksidan antara lain seperti asam askorbat, flavonoid, fenolat dan karotenoid yang berfungsi sebagai pelindung tubuh dari kerusakan sel-sel yang dapat diakibat radikal bebas. untuk mengetahui pengaruh pemberian ekstrak daun kelor (Moringa oleifera) sebagai upaya preventif terhadap kerusakan histopatologi pankreas tikus putih (Rattus norvegicus) galur Wistar jantan yang diinduksi aloksan. menggunakan metode eksperimental murni post test with control group design. Sampel yang digunakan sebanyak 30 ekor tikus jantan. Variabel yang diteliti adalah gambaran histopatologi pankreas. Analisa data menggunakan analisa univariat dan bivariat yang diolah dengan menggunakan system komputerisasi dengan uji Kruskal-Wallis. Hasil penelitian uji Kruskal-Wallis terdapat perbedaan yang signifikan antara kelompok perlakuan terhadap kerusakan histopatologi pankreas $(\mathrm{p}<0,05)$. terdapat pengaruh yang bermakna pemberian ekstrak daun kelor (Moringa oleifera) sebagai upaya preventif terhadap kerusakan histopatologi pankreas tikus putih (Rattus norvegicus) galur Wistar jantan yang diinduksi aloksan
\end{abstract}

Kata Kunci : Daun Kelor, Histopatologi, Pankreas, Aloksan

\section{PENDAHULUAN}

Pankreas merupakan suatu kelenjar majemuk bertandan, memiliki struktur yang sangat mirip dengan kelenjar ludah.
Kelenjar ini memiliki pajang kurang lebih $15 \mathrm{~cm}$, mulai dari duodenum sampai dengan limpa (Pearce, 2018). Pankreas berisi dua jenis jaringan utama, yaitu asini 
dan pulau-pulau Langerhans. Pulau Langerhans tersusun oleh tiga jenis sel utama yaitu sel alfa, sel beta, dan sel delta (Guyton and Hall, 2016). Sel alfa menghasilkan glukagon untuk meningkatkan glukosa darah, sel beta menghasilkan insulin untuk menurunkan gula darah atau glukosa darah agar kembali normal, sel delta menghasilkan sematostatin, yang menghambat kerja sel alfa dan sel beta (Eroschenko, 2015). Banyak fakor yang dapat menyebabkan kerusakan sel beta pankreas salah satu nya yaitu zat diabetogenik, zat diabetogenik yang dapat bersifat toksik adalah senyawa aloksan (Kunharjito dkk, 2018).

Obat tradisional sudah banyak sekali digunakan di kalangan masyarakat kelas menengah ke bawah terutama sebagai upaya pencegahan (preventif). Salah satu tumbuhan yang dapat dimanfaatkan baik sebagai sandang pangan maupun obatobatan ialah kelor (Putra, 2016). Daun kelor juga sudah dibuktikan oleh hasil penelitian dari lembaga terpercaya bahwa tidak memiliki efek samping (Winarno, 2018). Kandungan senyawa alami yang dikandung kelor memiliki jumlah yang lebih banyak dan banyak ragamnya dibanding jenis tanaman lainnya. Salah satu kandungan terkuat yang dimiliki tanaman kelor yaitu 46 antioksidan yang berfungsi sebagai pelindung tubuh dari kerusakan sel-sel yang dapat diakibat radikal bebas, kandungan antioksidan yang terdapat pada daun kelor antara lain seperti asam askorbat, flavonoid, fenolat dan karotenoid (Krisnadi, 2015).

Penelitian yang dilakukan Aini (2019) menyatakan bahwa pemberian ekstrak daun kelor (Moringa oleifera) pada dosis $150 \mathrm{mg} / \mathrm{kg}$ BB penurunan kadar glukosa darah lebih lambat dibandingkan dengan pemberian ekstrak daun kelor pada dosis $450 \mathrm{mg} / \mathrm{kg}$ BB (aini, 2019). Kerusakan sel beta pankreas menyebabkan tubuh tidak bisa menghasilkan insulin sehingga menyebabkan kadar glukosa darah meningkat (terjadi keadaan hiperglikemia) (Kunharjito dkk, 2018).
Penelitian ini bertujuan untuk mengetahui pengaruh pemberian ekstrak daun kelor (Moringa oleifera) sebagai upaya preventif terhadap kerusakan histopatologi pankreas tikus putih (Rattus norvegicus) galur Wistar jantan yang diinduksi aloksan.

\section{METODE}

Penelitian ini dilakukan di Laboratorium Universitas Malahayati pada bulan Januari 2021. Menggunakan metode eksperimental murni post test with control group design. Sampel yang digunakan sebanyak 30 ekor tikus putih galur Wistar jantan, berusia 2-3 bulan, berat badan 150250 gram dibagi menjadi 5 kelompok yaitu kelompok yang tidak diberi ekstrak daun kelor dan tidak diinduksi aloksan (KM). Kelompok yang diinduksi alkosan 125 $\mathrm{mg} / \mathrm{kgBB}(\mathrm{KN})$. Kelompok yang diberi metformin dosis $45 \mathrm{mg} / \mathrm{kgBB}$ dan diinduksi aloksan dosis $125 \mathrm{mg} / \mathrm{kgBB}$ (KP). Kelompok yang diberi ekstrak daun kelor dosis $150 \mathrm{mg} / \mathrm{kgBB}$ dan diinduksi aloksan dosis $125 \mathrm{mg} / \mathrm{kgBB}$ (P1) dan Kelompok yang diberi ekstrak daun kelor dosis $450 \mathrm{mg} / \mathrm{kgBB}$ dan diinduksi aloksan dosis $125 \mathrm{mg} / \mathrm{kgBB}$ (P2).

Kandang untuk pemeliharaan tikus yang terbuat dari bahan plastik dengan ukuran $55 \mathrm{~cm} \times 37 \mathrm{~cm} \times 16,5 \mathrm{~cm}$, kawat penutup, tempat untuk makan dan minum hewan coba, handscoon, masker, kapas, tissue, minor set, cover glass, objek glass, spuit 1cc, mikrotom, paraffin oven, cetakkan berbentuk kotak, mikropipet, sonde lambung, timbangan digital analitik, mikroskop cahaya dengan sumber arus listrik, alat untuk pembuatan preparat, alat tulis

Dalam penelitiian ini yang menjadi alat adalah Tikus putih (Rattus norvegicus) galur wistar jantan usia 2-3 bulan dan berat badan 150-250 gram, ekstrak daun kelor (Moringa oleifera), metformin, aloksan, pakan hewan coba standar Comfeed BR-II, aquadest, serbuk kayu, ketamine, kanada balsam, alkohol 96\%, zat pewarna 
Hematoxylin dan Eosin, paraffin, larutan xylol, alkohol $(70 \%, 80 \%, 90 \%, 95 \%)$ dan formalin.

Ekstraksi dilakukan di Laboratorium FMIPA yang terdapat di Universitas Lampung dengan menggunakan metode maserasi menggunakan pelarut etanol 96\%. Daun kelor di dapat dari perkebunan Universitas Malahayati, daun kelor diambil saat pagi hari, daun yang digunakan merupakan daun yang tidak terlalu tua dan tidak terlalu muda. Kemudian daun dicuci lalu dikeringkan dengan cara diangin-angkinkan saja selama kurang lebih 3 hari agar kandungan flavonoid yang terkandung dalam daun kelor tidak rusak. Dari proses preparasi daun kelor didapatkan hasil bahwa $3 \mathrm{~kg}$ daun kelor basah menghasilkan $1 \mathrm{~kg}$ daun kelor yang benar-benar kering. Daun kelor yang telah halus pada proses maserasi menggunakan pelarut etanol $96 \%$ bukan $70 \%$ karena alat uapnya tidak memiliki pompa, sehingga apabila menggunakan alkohol $70 \%$, maka proses penguapannya akan berjalan lambat, kemudian didiamkan selama 1 hari (24 jam) kemudian disaring, ulangi dimaserasi kembali sampai menghasilkan fliltrat yang jernih dan ini membutuhkan 5 kali penyaringan, Kumpulkan hasil yang telah disaring, kemudian uapkan dengan penguap vakum untuk memperoleh ekstrak yang kental selama 7 hari. Pengentalan ekstrak menggunakan alat penguap Rotary Vacum Evaporator dengan suhu 30-40 oC, tekanan $75 \mathrm{mmHg}$.

Hewan coba diperoleh dari pusat budidaya mencit dan tikus Di Palembang Tikus Centre. Hewan coba diaklimasi selama 7 hari, dipelihara dalam suhu sekitar $24^{\circ} \mathrm{C}$ dan kelembaban $55 \%$ serta memperoleh pencahayaan (siklus gelap terang selama 12 jam) yang cukup. Hewan coba ditempatkan dalam kandang individu dengan bentuk, ukuran, dan bahan yang sama. Selama masa aklimatisasi hingga masa perlakuan selesai, hewan coba mendapatkan pakan standar Comfeed BRII $100 \mathrm{gr} / \mathrm{kelompok} / \mathrm{hari}$ dan minum diberikan 2 kali sehari pada pukul 10:00 dan 16:00 dan dilakukan pada setiap hari. Pemberian ekstrak daun kelor dilakukan dengan menggunakan sonde lambung yang diberi secara peroral kepada hewan coba dan ekstrak daun kelor diberikan pada hari ke 8 sampai hari ke-28. Pemberian aloksan dilakukan pada hari ke-22 atau 14 hari setelah berjalannya pemberian ekstrak daun kelor. Tikus tidak diberikan makan dahulu selama 10 jam namun tetap diberi minum dan diberikan glukosa 5\% untuk menghindari hipoglikemia yang muncul sementara selama 30 menit akibat dari pemberian aloksan. Kemudian aloksan diberikan secara intraperitoneal dengan dosis $125 \mathrm{mg} / \mathrm{kgBB}$. Kemudian masuklah pada tahap terakhir yaitu pengambilan preparat pankreas pada hari ke-29 setelah pemberian aloksan dan pemberian ekstrak daun kelor. tikus akan dieuthanasia dengan melakukan dekapitasi pada bagian leher hewan coba. Setelah itu organ pankreas tikus diambil menggunakan peralatan bedah minor.

Organ pankreas tikus yang telah diambil, selanjutnya dilakukan pembuatan preparat pankreas dengan langkah sebagai berikut: Fiksasi, organ pankreas ditimbang di awetkan selama 1 malam dengan menggunakan formalin. Dehidrasi, mengeringkan pankreas yang telah diawetkan oleh formalin dengan cara memasukkan pankreas ke dalam alkohol. Clearing, memasukkan pankreas kedalam larutan xylene. Impregnasi, proses perendaman spesimen menggunakan paraffin I, paraffin II, dan paraffin III dengan lama waktu masing-masing 1 jam pada suhu kamar 56 0C. Embedding. tuangkan paraffin yang telah cair ke dalam tempat cetakan berbentuk segiempat tersebut hingga organ pankreas terbenam di tengah-tengah cetakan berbentuk segiempat tersebut dan siap untuk dimasukkan kedalam freezer. Cutting, tahap pemotongan organ pankreas yang bisa diambil menggunakan mikrotom. dan lembaran jaringan tersebut diambil menggunakan objek glass kemudian 
tempatkan ditengah usahakan agar tidak ada gelembung udara di bawah jaringan. Setelah itu keringkan ke dalam incubator selama 24 jam agar dapat melekat sempurna pada suhu 37 oC. Deparaffinisasi dan rehidrasi, setelah melekat dengan sempurna, preparat dimasukkan ke dalam xylol sebanyak 3 x 5 menit. Lalu lakukan tahap rehidrasi. Tahapan pewarnaan, menggunakan Hematoxylin Eosin. Kemudian sampel ditutup dengan objek glass, lalu amati preparat di bawah mikroskop cahaya.
Selanjutnya dilakukan pengecekan kelengkapan data dan melakukan entry data ke dalam software SPSS. Selanjutnya mengecek frekuensi distribusi, uji normalitas menggunakan Shapiro Wilk karena sampel pada penelitian ini $<50$. Namun data yang didapat tidak berdistribusi normal maka menggunakan uji Kruskal-wallis untuk mengetahui perbedaan antar kelompok perlakuan. Hasil uji Kruskal-Wallis menunjukkan terdapat perbedaan yang signifikan maka dilanjutkan uji Post Hoc Kruskal-Wallis.

\section{HASIL}

Penelitian dilakukan di Laboratorium Universitas Malahayati pada bulan JanuariFebruari 2021. Data diambil berdasarkan skor derajat kerusakan histopatologi pankreas.

Tabel 1. Karakteristik Sampel 2021

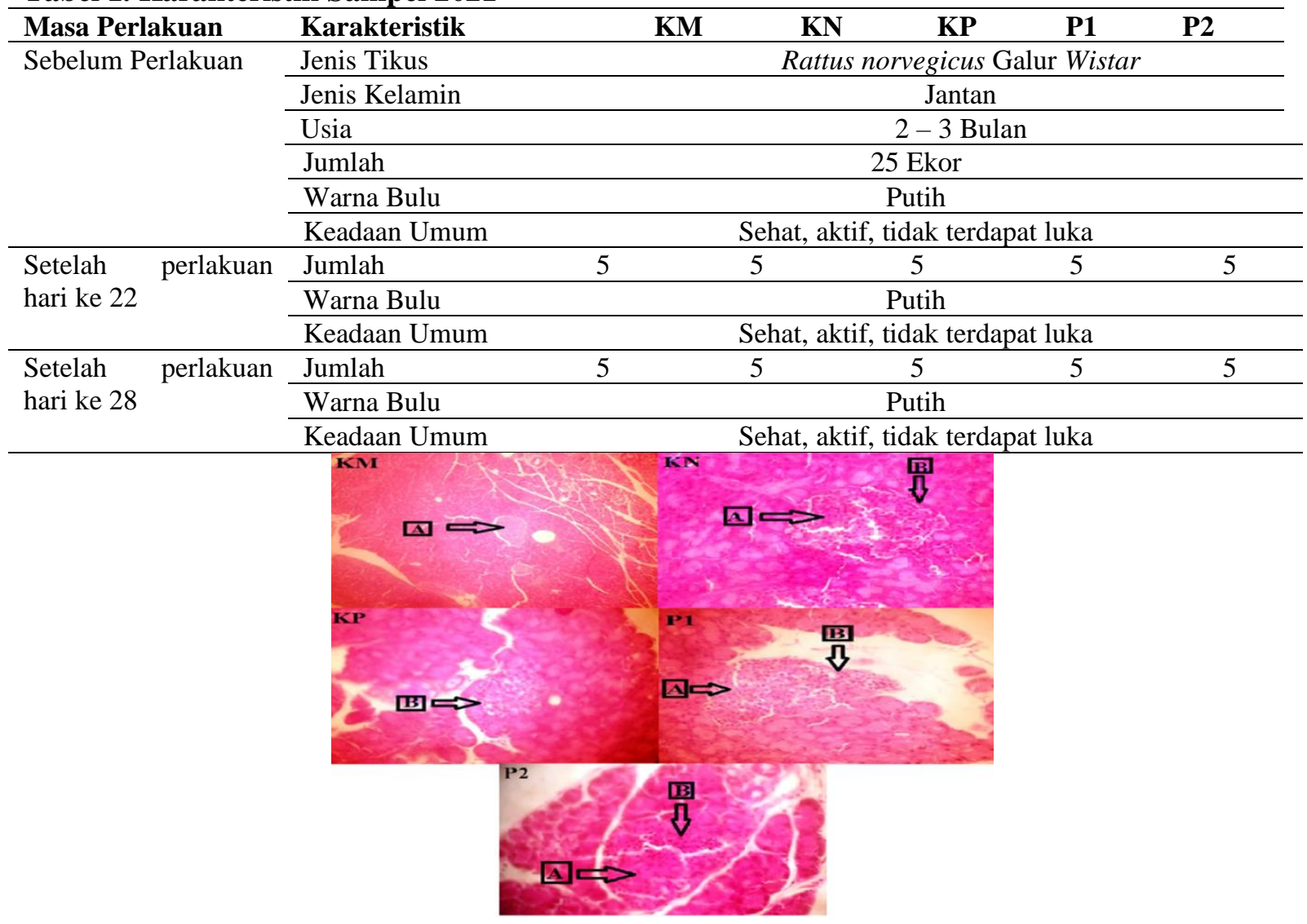

Gambar 1. Gambaran mikroskopis pancreas dengan perbesaran 400x. (A) Pulau langerhans (B) nekrosis sel.

Keterangan: KM: Kelompok kontrol murni yaitu kelompok yang tidak diberi ekstrak daun kelor dan tidak diinduksi aloksan. KN: Kelompok kontrol negatif yaitu kelompok yang diinduksi alkosan 125 $\mathrm{mg} / \mathrm{kgBB}$, KP: kelompok kontrol positif yaitu kelompok yang diberi metformin dosis 45 $\mathrm{mg} / \mathrm{kgBB}$ dan diinduksi aloksan dosis $125 \mathrm{mg} / \mathrm{kgBB}$,P1: Kelompok perlakuan 1 yaitu kelompok yang diberi ekstrak daun kelor dosis $150 \mathrm{mg} / \mathrm{kgBB}$ dan diinduksi aloksan dosis $125 \mathrm{mg} / \mathrm{kgBB}$ dan 
P2: kelompok perlakuan 2 yaitu kelompok yang diberi ekstrak daun kelor dosis $450 \mathrm{mg} / \mathrm{kgBB}$ dan diinduksi aloksan dosis $125 \mathrm{mg} / \mathrm{kgBB}$.

Data yang digunakan sebagai variabel dalam penelitian ini adalah gambaran histopatologi pankreas berupa ukuran pulau langerhns, jumlah pulau langerhans dan luas nekrosis sel yang diamati dengan menggunakan mikroskop untuk menghitung rerata skoring derajat kerusakan histopatologi pankreas dengan pembesaran 400x. Masing-masing preparat diamati pada lima lapangan pandang mikroskopis secara acak. Gambar 4.1. merupakan gambaran histopatologi paru dengan perbesaran 400x.

\section{Pengamatan Terhadap Histopatologi Pankreas}

Berdasarkan pengamatan rerata dari hasil penelitian yang dilakukan terhadap 25 ekor tikus putih (Rattus novergicus) galur Wistar jantan dapat dilihat pada gambar 2:

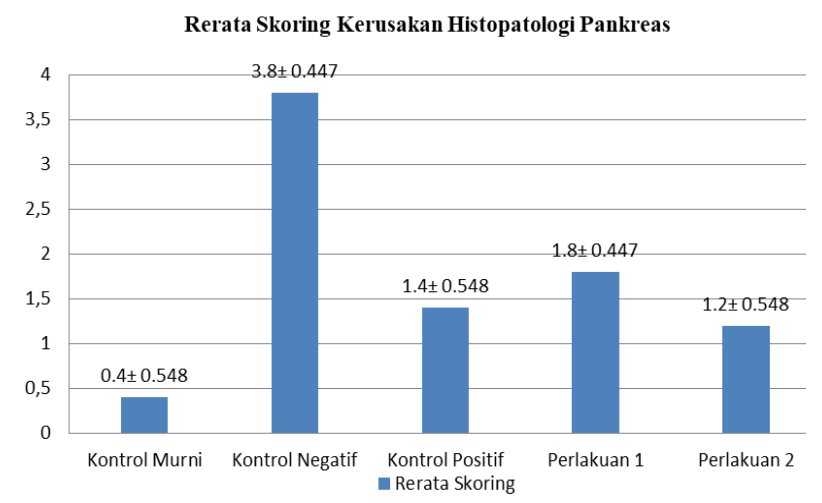

Gambar 2. Grafik Rerata Gambaran Histopatologi Pankreas

Keterangan: 1. Kelompok kontrol murni yaitu kelompok yang tidak diberi ekstrak daun kelor dan tidak diinduksi aloksan. 2. Kelompok kontrol negatif yaitu kelompok yang diinduksi alkosan 125 $\mathrm{mg} / \mathrm{kgBB}$, 3. kelompok kontrol positif yaitu kelompok yang diberi metformin dosis $45 \mathrm{mg} / \mathrm{kgBB}$ dan diinduksi aloksan dosis $125 \mathrm{mg} / \mathrm{kgBB}, 4$. Kelompok perlakuan 1 yaitu kelompok yang diberi ekstrak daun kelor dosis 150 $\mathrm{mg} / \mathrm{kgBB}$ dan diinduksi aloksan dosis $125 \mathrm{mg} / \mathrm{kgBB}$ dan 5. kelompok perlakuan 2 yaitu kelompok yang diberi ekstrak daun kelor dosis $450 \mathrm{mg} / \mathrm{kgBB}$ dan diinduksi aloksan dosis 125 $\mathrm{mg} / \mathrm{kgBB}$.
Gambar 2. menunjukkan rerata skoring derajat kerusakan histopatologi pankreas yang terjadi pada kelompok KM rata-rata $0,4 \pm 0,548$ kelompok $\mathrm{KN}$ ratarata 3,8 $\pm 0,447$ kelompok $\mathrm{KP}$ rata-rata $1,40 \pm 0,548$ kelompok $\mathrm{P} 1$ rata-rata 1,8 \pm 0,447 dan kelompok P2 rata-rata 1,2 \pm 0,447 . Setelah dilakukan uji normalitas, data yang ada tidak berdistribusi normal sehingga dilakukan uji non-parametrik Kruskal-Wallis untuk melihat ada atau tidaknya perbedaan pada kelompok perlakuan.

\section{Analisis Univariat}

\begin{tabular}{|c|c|c|c|c|}
\hline \multirow[t]{4}{*}{ Tabel } & \multirow{2}{*}{\multicolumn{4}{|c|}{$\begin{array}{l}\text { Distribusi Frekuen } \\
\text { Histopatologi Pankreas }\end{array}$}} \\
\hline & & & & \\
\hline & \multirow{2}{*}{\multicolumn{2}{|c|}{ Kelompok }} & \multicolumn{2}{|c|}{ Analisis Univariat } \\
\hline & & & Mean & $\begin{array}{l}\text { Standar } \\
\text { Deviasi }\end{array}$ \\
\hline \multirow{5}{*}{\multicolumn{2}{|c|}{$\begin{array}{l}\text { Histopatologi } \\
\text { Pankreas }\end{array}$}} & KM & 0.4 & 0.548 \\
\hline & & KN & 3.8 & 0.447 \\
\hline & & KP & 1.4 & 0.548 \\
\hline & & P1 & 0.8 & 0.447 \\
\hline & & P2 & 1.2 & 0.447 \\
\hline
\end{tabular}

Dapat diliahat pada tabel 2 . menunjukkan rerata skoring derajat kerusakan histopatologi pankreas yang terjadi pada kelompok yang tidak diberi ekstrak daun kelor dan tidak diinduksi aloksan (KM). Kelompok yang diinduksi alkosan $125 \mathrm{mg} / \mathrm{kgBB}(\mathrm{KN})$. Kelompok yang diberi metformin dosis $45 \mathrm{mg} / \mathrm{kgBB}$ dan diinduksi aloksan dosis $125 \mathrm{mg} / \mathrm{kgBB}$ (KP). Kelompok yang diberi ekstrak daun kelor dosis $150 \mathrm{mg} / \mathrm{kgBB}$ dan diinduksi aloksan dosis $125 \mathrm{mg} / \mathrm{kgBB}$ (P1) dan Kelompok yang diberi ekstrak daun kelor dosis $450 \mathrm{mg} / \mathrm{kgBB}$ dan diinduksi aloksan dosis $125 \mathrm{mg} / \mathrm{kgBB}$ (P2). Menunjukkan kerusakan pada kelompok KM rata-rata $0,4 \pm 0,548$ kelompok KN rata-rata 3,8 \pm 0,447 kelompok KP rata-rata 1,40 $\pm 0,548$ kelompok $\mathrm{P} 1$ rata-rata $1,8 \pm 0,447$ dan kelompok $\mathrm{P} 2$ rata-rata $1,2 \pm 0,447$. Terdapat perbedaan rerata skoring antar kelompok perlakuan. 
Analisis Bivariat

Tabel 3. Pengaruh Antara Kelompok Perlakuan Terhadap Kerusakan Histopatologi Pankreas

\begin{tabular}{lr}
\hline & \multicolumn{2}{r}{ Histopatologi pankreas } \\
\hline Kruskal_wallis H & 18.764 \\
\hline df & 4 \\
\hline Asymp. Sig. & 0.001 \\
\hline
\end{tabular}

Berdasarkan tabel 3. uji KruskalWallis untuk melihat terdapat atau tidak perbedaan pada kelompok perlakuan. Berdasarkan hasil uji diatas dapat diketahui nilai Asymp. Sig adalah sebesar $0,001(\mathrm{p}=0,001)$ maka nilai tersebut lebih kecil daripada $0,05 \quad(\mathrm{p}<0,05)$. Dengan demikian terdapat perbedaan yang signifikan antara kelompok perlakuan terhadap kerusakan histopatologi pankreas.

Tabel 4. Peringkat Rata-rata Antara Kelompok Perlakuan Terhadap Kerusakan Histopatologi Pankreas

\begin{tabular}{|c|c|c|c|}
\hline \multicolumn{2}{|c|}{ Kelompok } & $\mathbf{N}$ & Mean Rank \\
\hline \multirow{2}{*}{$\begin{array}{l}\text { Histopatologi } \\
\text { Pankreas }\end{array}$} & $\mathrm{KM}$ & 5 & 4.60 \\
\hline & KN & 5 & 23.00 \\
\hline & KP & 5 & 11.90 \\
\hline & P1 & 5 & 15.30 \\
\hline & $\mathrm{P} 2$ & 5 & 10.20 \\
\hline & TOTAL & 25 & \\
\hline
\end{tabular}

Berdasarkan tabel 4. dapat dilihat bahwa nilai mean rank pada masingmasing kelompok berbeda yang mana mean rank kelompok kontrol murni (KM) sebesar 4.60, kelompok kontrol negative (KN) sebesar 23.00, kelompok kontrol positif (KP) sebesar 11.90, kelompok perlakuan 1 (P1) sebesar 15.30, dan kelompok perlakuan 2 (P2) sebesar 10.20. Dapat dilihat berdasarkan nilai mean rank pada kelompok kontrol murni (KM) memiliki nilai mean paling kecil di antara semua kelompok perlakuan yang artinya kelompok tersebut memiliki skoring derajat kerusakan histopatologi pankreas yang paling kecil dan dapat dilihat berdasarkan nilai mean rank pada kelompok kontrol negarif $(\mathrm{KN})$ memiliki nilai mean rank paling besar di antara semua kelompok perlakuan yang artinya kelompok tersebut memiliki skoring derajat kerusakan histopatologi pankreas yang paling besar. Kemudian dilanjutkan kelompok kontrol positif (KP), kelompok perlakuan 1 (P1) dan kelompok perlakuan 2 (P2) dimana diantara tiga kelompok tersebut nilai mean rank terbesar dimiliki oleh kelompok perlakuan 1 (P1) dan yang memiliki nilai terkecil yaitu kelompok perlakuan $2(\mathrm{P} 2)$ yaitu sebesar 10.20.

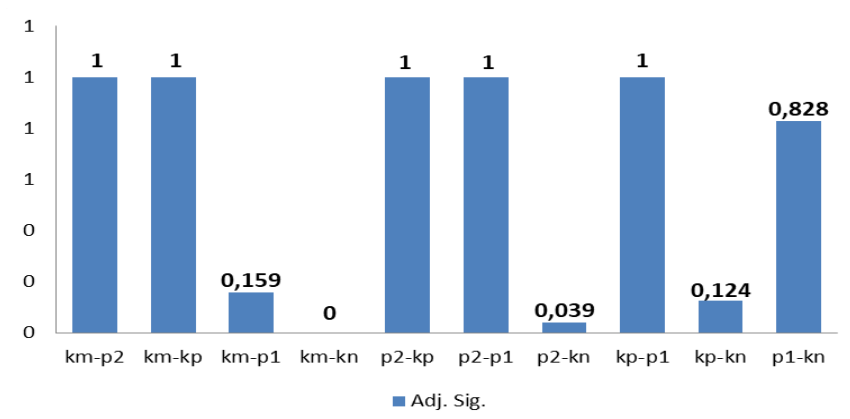

Gambar 3. Grafik Post Hoc Kruskal Wallis

Berdasarkan gambar 3. Grafik Post Hoc Kruskal Wallis menunjukkan kelompok yang memiliki perbedaan yang signifikan yaitu kelompok kontrol murni (KM) dan kontrol negative (KN) dengan nilai Adj. Sig. sebesar 0,00 dan pada kelompok perlakuan 2 (P2) dan kontrol negative $(\mathrm{KN})$ dengan nilai Adj. Sig. sebesar 0,039 .

\section{PEMBAHASAN}

Pankreas adalah sebuah kelenjar memanjang yang terletak di belakang dan di bawah lambung di atas lengkung pertama duodenum (Sherwood, 2014). Pankreas terdiri dari dua jenis jaringan utama, yaitu asini dan pulau-pulau Langerhans (Guyton and Hall, 2016). Adanya zat diabetogenik yang masuk kedalam tubuh dapat menyebabkan sel-sel beta pada pulau langerhans rusak. Kerusakan sel beta pankreas menyebabkan tubuh tidak bisa menghasilkan insulin sehingga menyebabkan kadar glukosa darah meningkat (terjadi keadaan hiperglikemia) (Kunharjito dkk, 2018). 


\section{Pengaruh Pemberian Ekstrak Daun Kelor Terhadap Kerusakan Hitopatologi Pankreas}

Dilihat dari mean rank yang didapat dari hasil pengujian Kruskal-Wallis, kontrol murni (KM) memiliki nilai mean rank paling kecil di antara semua kelompok perlakuan yaitu sebesar 4,60 $(0,4 \pm 0,548)$ yang artinya kelompok tersebut memiliki skoring derajat kerusakan histopatologi pankreas yang paling kecil. Ini dapat dilihat dari gambaran histopatologi yang diambil melalui mikroskop dengan perbesaran 400x pada 5 lapang pandang dimana didapatkan jumlah pulau langerhans sebanyak 7/5 LPB, ukuran pulau langerhans yang normal, dan nekrosis sel$\beta$ yang mencapai $0 \%$. Hal ini dikarenakan pada KM tidak dilakukan perlakuan seperti pemberian ekstrak daun kelor, pemberian metformin, ataupun induksi aloksan. Apabila terdapat peningkatan skor kerusakan pada KM kemungkinan dapat disebabkan pada penelitian ini tikus tersebut sudah memiliki kelainan pada pankreas walaupun peningkatannya tidak signifikan. Hal ini senada dengan hasil penelitian zubaidah dan nuril (2015) pada tikus normal tanpa perlakuan menunjukkan adanya keteraturan susunan sel endokrin yang menyebar di pulau Langerhans dengan bentuk sel yang seragam dan ukuran sitoplasma terlihat proporsional terhadap inti serta tidak mengalami perubahan. Selain itu kondisi sel-beta dan sel alfa dalam keadaan relatif baik yang ditandai dari kondisi islet langerhans yang relatif rapat (Zubaidah \& Nuril, 2015).

Kelompok kontrol negatif (KN) memiliki nilai mean rank paling besar di antara semua kelompok perlakuan yaitu sebesar 23,00 $(3,8 \pm 0,447)$ yang artinya kelompok tersebut memiliki skoring derajat kerusakan histopatologi pankreas yang paling besar. Ini dapat dilihat dari gambaran histopatologi yang diambil melalui mikroskop dengan perbesaran 400x pada 5 lapang pandang dimana didapatkan jumlah pulau langerhans sebanyak 6/5 LPB, ukuran pulau langerhans yang kecil, dan nekrosis sel- $\beta$ yang mencapai $50 \%$. Hal ini disebabkan karena pada kelompok $\mathrm{KN}$ hanya diinduksi aloksan $125 \mathrm{mg} / \mathrm{kgBB}$. Penelitian sebelumnya melaporkan, kerusakan histopatologi pankreas diabetes ditandai dengan perubahan bentuk dari pankreas berupa penyusutan dan pengurangan ukuran dari pulau Langerhans (Walean dkk, 2020). Hal ini senada dengan hasil penelitian Pratama dkk (2020) pada kelompok hewan coba yang diberi aloksan, menunjukkan peningkatan derajat kerusakan pankreas yang digambarkan dengan gambaran histopatologi pankreas yang bermakna $(\mathrm{p}=0,001) \quad$ jika dibandingkan dengan kelompok hewan coba yang diberi pakan standard. Keadaan tersebut menunjukkan bahwa telah terjadi kerusakan pankreas dikarenakan pemberian aloksan. Hal ini dibuktikan dengan terjadinya kerusakan pada sel beta pankreas dimana sel beta pankreas mengalami nekrosis yang ditandai dengan kondisi piknotik pada sel dan mengalami kariolisis (Pratama dkk, 2020). Aloksan adalah suatu zat kimia atau agen oksidan yang kuat yang dapat menyebabkan kerusakan sel. Aloksan biasa digunakan untuk menginduksi diabetes pada hewan coba, pemberian aloksan adalah suatu cara yang cepat untuk mendapatkan kondisi diabetic eksperimental (hiperglikemia) pada hewan coba (Rohilla \& Shahjad, 2012). Aloksan dapat menyebabkan keadaan diabetes melitus karena aloksan bersifat toksik selektif terhadap sel- $\beta$ pankreas yang merupakan suatu sel pada pankreas yang berguna untuk menghasilkan insulin, disebabkan karena terakumulasinya aloksan secara khusus melalui transporter glukosa yaitu GLUT-2 (Rohilla \& Shahjad, 2012).

Pada kelompok KP dengan mean rank $11.90(1,4 \pm 0,548)$ terjadi perbaikan pada kelompok ini yaitu kelompok yang diberi metformin $45 \mathrm{mg} / \mathrm{kgBB}$ dan diinduksi 
aloksan $125 \mathrm{mg} / \mathrm{kgBB}$. Dapat dilihat dari gambaran histopatologis pankreas dimana didapatkan jumlah pulau langerhans 7/5 LPB dengan ukuran pulau langerhans normal dan nekrosis sel sebesar $10 \%$. Hal ini diduga akibat dari pemberian metformin. Hasil penelitian ini senada dengan hasil penelitian Fitri dan Yuniarti (2019) menunjukkan pada kelompok yang diberi metformin dan aloksan mengalami perbaikan pulau Langerhans, namun perlakuan yang paling efektif untuk meningkatkan jumlah sel pankreas yaitu kelompok yang diberi aloksan, metformin dan air rebusan daun kembang bulan 49.1 $\mathrm{mg} / 10 \mathrm{ml}$ karena kandungan senyawa flavonoid dan tanin dari air rebusan daun kembang bulan (Fitri \& Yuniarti, 2019). Hal ini juga senada dengan penelitian yang dilakukan oleh Tjandrawinata (2014) yang menyatakan bahwa metformin memiliki khasiat yang unik yaitu menyangkut salah satu hormon pencernaan. Hormon yang dimaksud adalah incretin khususnya GLPyang diproduksi oleh usus halus. Hormon ini dikenal meningkatkan kepekaan sel beta pankreas terhadap rangsangan glukosa untuk menghasilkan insulin. Hormon ini berperan penting pula dalam menjaga kadar glukosa darah agar normal melalui keseimbangan kerja antara insulin dan glukagon. Khasiat Metformin adalah dalam kerjanya menghambat proses degradasi dari GLP-1 dalam tubuh. Metformin juga berpengaruh dalam penurunan stress oksidatif melalui jalur pembentukan AGEs dan peningkatan senyawa karbonil (Tjandrawinata, 2014). Metformin sangat mudah di dapatkan namun Metformin memiliki efek samping berupa mual, muntah, hipoglikemia, pusing, tremor (Putra, 2017).

Pada kelompok perlakuan 1 (P1) dan perlakuan 2 (P2) dimana perlakuan 1 (P1) hewan coba diberikan ekstrak daun kelor dengan dosis $150 \mathrm{mg} / \mathrm{kgBB}$ dan diinduksi aloksan dengan dosis $125 \mathrm{mg} / \mathrm{kgBB}$ dan pada perlakuan 2 (P2) hewan coba diberikan ekstrak daun kelor dengan dosis $450 \mathrm{mg} / \mathrm{kgBB}$ dan diinduksi aloksan dengan dosis 125mg/kgBB. Pada perlakuan 1 (P1) dengan nilai mean rank sebesar $15.43(1,8 \pm 0,447)$ dan pada perlakuan 2 (P2) mean rank yang di dapatkan sebesar $10.20(1,2 \pm 0,447)$.

Terjadi perbaikan pada gambaran histopatologi pankreas yang dapat dilihat dari jumlah pulau langerhans, ukuran pulau langerhans, dan luas nekrosis pada sel- $\beta$. Pada perlakuan 1 (P2) gambaran histopatologi didapatkan jumlah pulau langerhans 6/5LPB dengan ukuran pulau langerhans yang kecil dan terjadi nekrosis sel- $\beta$ sebesar $10 \%$. Pada perlakuan 2 (P2) gambaran histopatologi didapatkan jumlah pulau langerhans 7/5 LPB dengan ukuran pulau langerhans yang normal dan terjadi nekrosis sel- $\beta$ sebesar $10 \%$. Perbaikan pada gambaran histopatologi pankreas yang telah diinduksi aloksan ini disebabkan oleh pemberian ekstrak daun kelor dimana daun kelor ini mengandung banyak senyawa alami salah satunya tanaman kelor mengandung 46 antioksidan terkuat (Krisnadi, 2015). Antioksidan merupakan senyawa yang dapat menghambat ROS dan juga radikal bebas sehingga antioksidan dapat mencegah penyakit-penyakit yang dihubungkan dengan radikal bebas seperti kanker, aterosklerosis dan diabetes melitus (Soviana, 2014). Antioksidan melindungi tubuh dari radikal bebas dengan menetralkan radikal bebas dengan cara menyumbangkan elektron sehingga membuatnya stabil kembali sebelum dapat menyebabkan kerusakan sel dan menjadi penyakit. Kandungan antioksidan yang terdapat pada daun kelor antara lain seperti asam askorbat (vitamin $\mathrm{C}$ ), flavonoid, fenolat dan karotenois ( $\beta$-karoten) (Krisnadi, 2015), Meskipun daun kelor belum ada dalam bentuk ekstraknya namun daun kelor lebih alami, dapat dikonsumsi dalam berbagai macam olahan dan daun kelor telah dibuktikan oleh hasil penelitian dari lembaga terpercaya tidak memiliki efek samping serta baik dikonsumsi oleh anak ataupun dewasa (Winarno, 2018). 
Berdasarkan hasil dari uji KruskalWallis kelompok yang memiliki nilai mean rank yang lebih kecil terdapat pada kelompok perlakuan 2 (P2) yaitu pemberian ekstrak daun kelor dengan dosis $450 \mathrm{mg} / \mathrm{kgBB}$ dan diinduksi aloksan dengan dosis $125 \mathrm{mg} / \mathrm{kgBB}$ dibandingkan dengan pemberian ekstrak daun kelor dengan dosis $150 \mathrm{mg} / \mathrm{kgBB}$ dan diinduksi aloksan dengan dosis $125 \mathrm{mg} / \mathrm{kgBB}$, sehingga dosis yang paling berpengaruh terhadap gambaran histopatologi pankreas tikus putih (Rattus norvegicus) galur Wistar jantan yang diinduksi aloksan yaitu dosis $450 \mathrm{mg} / \mathrm{kgBB}$. Hal yang sama juga dinyatakan oleh aini (2019) bahwa pemberian ekstrak daun kelor (Moringa oleifera) pada dosis $150 \mathrm{mg} / \mathrm{kg}$ BB penurunan kadar glukosa darah lebih lambat dibandingkan dengan pemberian ekstrak daun kelor pada dosis $450 \mathrm{mg} / \mathrm{kg}$ BB (aini, 2019). Kerusakan sel beta pankreas menyebabkan tubuh tidak bisa menghasilkan insulin sehingga menyebabkan kadar glukosa darah meningkat (terjadi keadaan hiperglikemia) (Kunharjito dkk, 2018).

Dapat dilihat dari persentase nekrosis pada P1 dan P2 dengan pemberian ekstrak daun kelor sebagai upaya preventif sangat membantu mengurangi nekrosis sel dibandingkan dengan pemberian ekstrak daun kelor sebagai pengobatan. Hal ini sejalan dengan penelitian yang dilakukan oleh tandi (2019) yang menyatakan bahwa tikus yang diberi ekstrak daun kelor fraksi etanol mengalami nekrosis mencapai 50$75 \%$ dan menyatakan bahwa Fraksi yang efektif menurunkan kadar glukosa darah dan meregenerasi sel beta pankreas adalah fraksi etanol air dibandingkan fraksi nheksan mengandung saponin, fraksi etil asetat mengandung alkaloid, flavonoid, saponin, tannin, fenolik dan triterpenoid (steroid), dan fraksi etanol air mengandung alkaloid, flavonoid, saponin, tannin, dan fenolik (tandi, 2019).

\section{KESIMPULAN}

Berdasarkan hasil analisis dan pembahasan yang telah diuraikan oleh peneliti, dapat diambil kesimpulan berupa: Terjadi pengaruh yang bermakna pemberian ekstrak daun kelor (Moringa oleifera) sebagai upaya preventif terhadap kerusakan histopatologi pankreas tikus putih (Rattus norvegicus) galur Wistar jantan yang diinduksi aloksan.

\section{UCAPAN TERIMAKASIH}

Ucapan terimakasih diucapkan kepada semua pihak yang telah terlibat dalam penelitian ini sehingga pengetahuan yang terdapat dalam penelitian ini dapat dituangkan dalam bentuk tulisan dan diinformasikan kepada pembaca

\section{DAFTAR PUSTAKA}

Aini Qurratu. 2019. Penentuan Ekstrak Daun Kelor (Moringa oleifera) Dalam Menurunkan Glukosa Darah Pada Tikus Hiperglikemik Di Laboratorium. Semdi Unay. http://jurnal.abulyatama.ac.id/index.ph p/semdiunaya.

Eroschenko, V. P. 2015. Atlas Histologi DiFiore Dengan Korelasi Fungsional. Edisi 12. Jakarta : EGC.

Evelyn C. Pearce. 2018. Anatomi Dan Fisiologi Untuk Paramedis. Jakarta: PT Gramedia.

Fitri Y, Yuniarti E. 2019. Effect of Boiled Water Tithonia diversifolia A. Gray Leaf Against the Pancreas Histology in Mus musculus L. Induced by Alloxan. Bioscience Volume 3 Number 1, 69-78. ISSN: Print 14129760 - Online 2541-5948 DOI: 10.24036/0201931103432-0-00 http://ejournal.unp.ac.id/index.php/bio $\underline{\text { scienc }}$

Guyton, A.C. dan Hall, J.E. 2016. Buku Ajar Fisiologi Kedokteran. Edisi 12. Jakrta: EGC.

Krisnadi A.D. 2015. E-book Kelor Super Nutrsi. Pusat Informasi Dan Pengembangan Tanaman Kelor 


\section{ISSN 2623-1581 (Online) \\ ISSN 2623-1573 (Print)}

Indonesia Lembaga Swadaya

Masyarakat - Media Peduli

Lingkungan (LSM-MEPELING).

Blora: Indonesia.

Kunharjito W.A.C, Avesina M, Anggriyawati D.P, Purnama E.R. 2018. Pemanfaatan Daun Kelor (Moringa oleifera) Terhadap Pemulihan Struktur Pankreas Mencit Diabetik. Biotropic The Journal of Tropical biology. Vol 2. No 2. ISSN 25805029.

Putra I.W.D.P, Dharmayudha A.A.G.O, Sudimartini L.M. 2016. Identifikasi Senyawa Kimia Ekstrak Etanol Daun Kelor (Moringa oleifera L) di Bali. Indonesia Medicus Veterinus. pISSN : 2301-7848; eISSN : 2477-6637. 5(5) : 464-473.

Pratama R.Y, Pranitasari N, Purwaningsari D. 2020. Pengaruh Ekstrak Daun Sirsak Terhadap Gambaran Histopatologi Pankreas Rattus Norvegicus Jantan yang Diinduksi Aloksan. HTMJ Volume 17 nomer 2

Putra R.J.S, dkk. 2017. Kejadian Efek Samping Potensial Terapi Obat Anti Diabetes Pasien Diabetes Melitus Berdasarkan Algoritma Naranjo. PHARMACEUTICAL JOURNAL OF INDONESIA. 2(2): 45-50

Rohilla, A., \& Ali, S. 2012. Alloxan induced diabetes: mechanisms and effects. International journal of research in pharmaceutical and biomedical sciences, 3(2), 819-823.

Sherwood L. 2014. Fisiologi Manusia Dari Sel Ke Sistem. Edisi 8. Jakarta : EGC
Soviana E, Rachmawati B, Suci N. 2014. Pengaruh suplementasi $\beta$-carotene terhadap kadar glukosa darah dan kadar malondialdehida pada tikus sprague dawley yang diinduksi Streptozotocin. Jurnal Gizi Indonesia (ISSN : 1858-4942). Vol. 2 No. 2.

Tandi, J. 2019. Uji Efektivitas Antihiperglikemia Daun Kelor (Moringa Oleifera Lam.) dan Gambaran Histopatologi Pankreas Tikus Putih Jantan (Rattus Norvegicus) yang Diinduksi Streptozotocin. Jurnal Jamu Indonesia 4(2): 63-73

Tjandrawinata Raymond R, 2014. Medicinus Scientific Journal Of Pharmaceutical Development And Medical Application "Diabetes Mellitus". Vol 27, No 2. ISSN 1979.

Walean M, dkk. 2020. Perbaikan Histopatologi Pankreas Tikus Hiperglikemia setelah Pemberian Ekstrak Etanol Kulit Batang Pakoba (Syzygium luzonense (Merr.) Merr.) Majalah Ilmiah Biologi Biosfera : A Scientific Journal DOI: 10.20884/1.mib.2020.37.1.1210 Vol 37, No 1 Januari $2020: 43$ - 48

Winarno F.G. 2018. Tanaman Kelor (Moringa oleifera). Jakarta: PT Gramedia.

Zubaidah E, dan Nuril I. 2015. Efek Cuka Apel dan Cuka Salak terhadap Penurunan Glukosa Darah dan Histopatologi Pankreas Tikus Wistar Diabetes. Jurnal Kedokteran Brawijaya. Vol. 28 No. 4. 